\title{
Five new species of Smicridea McLachlan (Trichoptera, Hydropsychidae) from Brazil ${ }^{1}$
}

\author{
Gisele L. de Almeida ${ }^{2}$ \\ Oliver S. Flint Jr. ${ }^{3}$
}

\begin{abstract}
Five new species of Smicridea McLachlan, 1971, are described and illustrated for specimens collected during entomological inventories in the states of Espírito Santo, Goiás, Rio de Janeiro, São Paulo and Paraná (Brazil). Four of these new species belong to the subgenus Rhyacophylax Müller, 1879: $S$. (R.) froehlichi, $S$. (R.) jundiai, $S$. (R.) mangaratiba, $S$.(R.) ralphi, and one to the subgenus Smicridea McLachlan, 1871: S. (S.) mirnae.

KEY WORDS. Trichoptera, Smicridea, new species, Brazil, inventory
\end{abstract}

Smicridea McLachlan, 1871, is the most diverse and abundant genus so far recognized in the family Hydropsychidae, with more than 160 species described for the Neotropics (FLINT et al. 1999). This is the only genus of the subfamily Hydropsychinae occurring in South America (FLINT 1974), where still exists a scarcity of inventories of aquatic insects, and in particular, of Trichoptera (FLINT 1971, 1978, 1992; Oliveira \& FroeHLiCH 1997; ALMEIDA \& MARINONI 2000; MARINONI \& ALMEIDA 2000). The genus Smicridea comprises two subgenera, Smicridea MacLchlan, 1871, and Rhyacophylax Müller, 1879, which have been the subject of some studies in the Neotropics (FLINT 1967, 1972, 1974, 1978, 1981, 1983, 1989, 1991; Flint \& DENNING 1989; BLAHNIK 1995; Holzenthal \& BLAHNIK 1995).

Before the present paper, 30 described species of Smicridea had been recorded for Brazil (FLINT et al. 1999; MARINONI \& ALMEIDA 2000). In this contribution, five new species are described, four of these species belonging to the subgenus Rhyacophylax and one to the subgenus Smicridea: Smicridea (Rhyacophylax) froehlichi, Smicridea (Rhyacophylax) jundiai, Smicridea (Rhyacophylax) mangaratiba, Smicridea (Rhyacophylax) ralphi and Smicridea (Smicridea) mirnae. These species were collected during entomological inventories in the states of Espírito Santo, Goiás, Rio de Janeiro, São Paulo and Paraná. Specimens from southern Brazil were obtained after the entomological inventory, called PROFAUPAR (Projeto de Levantamento da Fauna Entomológica no Estado do Paraná),

1) Contribution number 1343 of the Departamento de Zoologia, Universidade Federal do Paraná.

2) Departamento de Zoologia, Universidade Federal do Paraná, Caixa Postal 19020, 81531-980 Curitiba, Paraná, Brasil. Fellowship from CAPES.

E-mail: giseleluziane@yahoo.com

3) National Museum of Natural History, Department of Systematic Biology, Section of Entomology, Smithsonian Institution, 20560, Washington, DC, USA.

E-mail: flint.oliver@nmnh.si.edu 
conducted by research scientists of the Departamento de Zoologia, Universidade Federal do Paraná (see details in MARINONI \& DUTRA 1993). All material of the PROFAUPAR inventory is preserved in $70 \%$ ethanol.

Holotypes and paratypes are deposited, as stated in the descriptions, in the collections of the National Museum of Natural History, Smithsonian Institution, Washington, DC, USA (NMNH), Coleção de Entomologia Padre Jesus Santiago Moure, Departamento de Zoologia, Universidade Federal do Paraná, Curitiba, Brazil (DZUP), and Museu de Zoologia, Universidade de São Paulo, São Paulo, Brazil (MZUSP).

\section{Smicridea (Rhyacophylax) froehlichi sp. nov.}

Fig. 1a-d

This is a very distinct species, based on the structure of the phallus and not apparently closely related to any other known species in the subgenus. The very broad basal section of the phallus, the pointed, apicolateral lobes and lack of apicomesal process but with long, slender more basal processes in the phallus give a most distinctive appearance.

Male. Length of forewing 6.0-7.0 mm. Color overall yellowish brown; forewing with light brown marks along chord, over radial and thyridial nygmas, base of costal margin, and pterostigma, apex of wing with slightly dark subterminal band. Sternum V in male with anterolateral glandular process slightly longer than sternum. Genitalia as in figure la-d. Segment IX with anterolateral margin produced into a large, rounded lobe, dorsomesally with a small prominence bearing spicules, ventromesal margin pointed. Tergum X, in lateral view, with tip rounded; setose apicodorsally; ventrolateral margin of $X$ strongly sclerotized; apex of $X$ divided to about half-length of tergum. Inferior appendages two-segmented; basal segment long, slightly inflated mesally, covered with setae; apical segment short, apex slightly enlarged in dorsal view. Phallus tubular, basal section very enlarged and meeting apical section at about $75^{\circ}$; apex of phallus with a pair of pointed lateral processes; internal processes long, slender, and displaced basad; dorsal periphallic membranes absent.

Female. Length of forewing 4.0-7.3 mm. Color and structure similar to male. Genitalia typical for genus.

Type material. Holotype male. BRAZIL, Rio de Janeiro: Km 17, $18 \mathrm{~km} \mathrm{~S}$. of Teresópolis, 1180 m, 18-19.IV.1977, C.M. \& O.S. Flint Jr. leg. (MZUSP). Paratypes: same data as holotype, 18 males, 10 females (DZUP, NMNH, MZUSP); Goiás: Chapada dos Veadeiros, 18-24 km, N. of Alto Paraíso, 1400-1500 m, 2-5.X.1985, S.E. Miller leg., 3 males, 1 female (NMNH); Alto Paraíso, 1300 m, 10.II.1996, V.O. Becker leg., 3 males, 2 females (NMNH); 30.V.1994, V.O. Becker \& K.S. Sattler leg., 1 female (NMNH); Rio de Janeiro: Mangaratiba, 150 m, 20.I.1993, V.O. Becker leg., 3 males, 3 females (NMNH); Nova Friburgo, municipal water supply, 950 m, 20.IV.1977, C.M. \& O.S. Flint Jr. leg., 2 males, 1 female; 24.IV.1977, 4 males, 5 females (NMNH); Nova Friburgo, 800 m, 22.I.1993, V.O. Becker leg., 2 males, 2 females (NMNH); Nova Friburgo, 600 m, 10.III.1993, V.O. Becker leg., 9 males, 2 females (NMNH); Km 54, 26 km E. of Nova Friburgo, 410 m, 19.IV.1977, C.M. \& O.S. Flint Jr. leg., 16 
males, 6 females (DZUP, NMNH, MZUSP); 25.IV.1977, 7 males, 4 females (NMNH); Rio de Janeiro, Parque Nacional da Tijuca, Represa dos Ciganos, 07.IV. 1977, C.M. \& O.S. Flint Jr. leg., 2 males, 2 females (NMNH).

Etymology. The species is named for Dr. Claudio G. Froehlich for his outstanding contributions to the knowledge of Neotropical Plecoptera and aquatic insects in general.
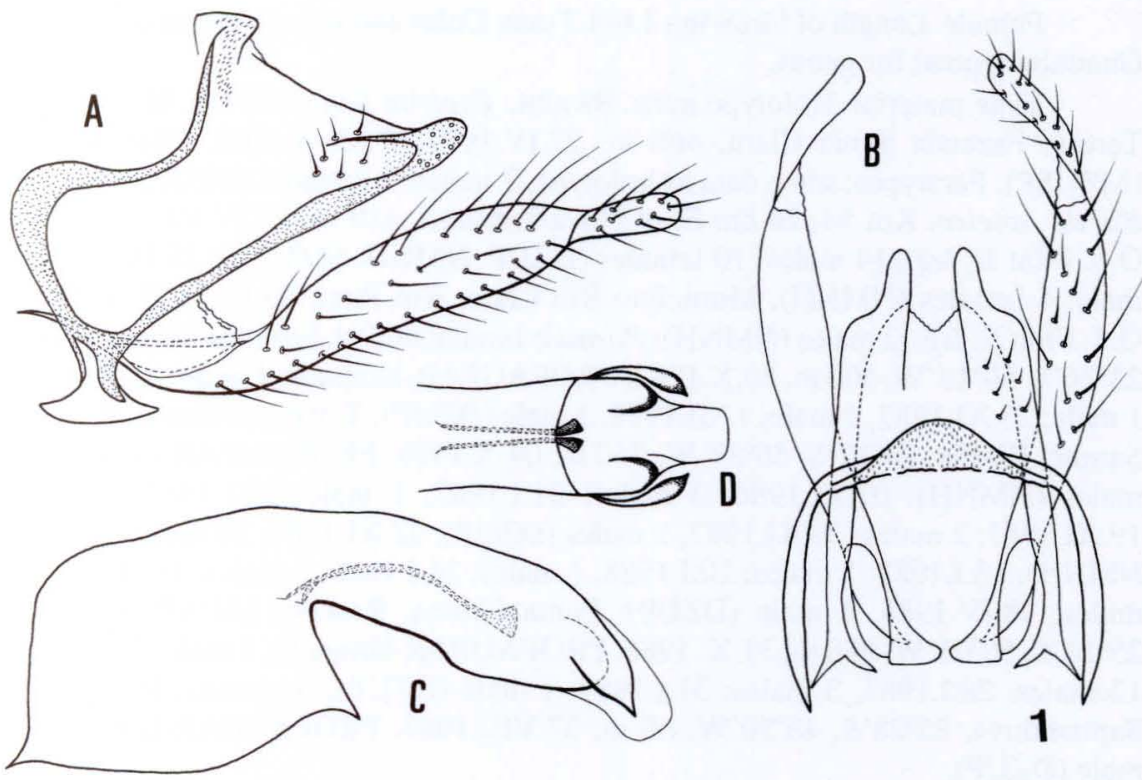

Fig. 1. Smicridea (Rhyacophylax) froehlichisp. nov., male genitalia: (A) segments IX, X, lateral, and inferior appendage; (B) same, dorsal; (C) phallus, lateral; (D) apex of same, ventral.

\section{Smicridea (Rhyacophylax) jundiai sp. nov.}

Fig. 2a-d

The similar appearance of the internal processes of the phallus shows a relationship to $S$. (R.) pallidivittata Flint, 1972. However, the apicolateral lobes of the phallus, very apparent in dorsal view, are totally lacking in $S$. (R.) pallidivittata.

Male. Length of forewing 4.0-4.5 mm. Color overall pale brown; forewing with dark marks along chord and over radial and thyridial nygmas, apex of wing with a subterminal band of pale setae, bordered basally and apically by bands of slightly darker setae. Sternum V in male with anterolateral glandular process slightly shorter than sternum. Genitalia as in figure 2a-d. Segment IX with anterolateral margin moderately produced, dorsomesally bearing small spicules. Tergum X, in lateral view, with tip elongate, rounded, slightly upturned; setose apicodorsally; ventrolateral margin of $\mathrm{X}$ strongly sclerotized; apex of X divided to about half- 
length of tergum. Inferior appendages two-segmented; basal segment long, parallel sided, covered with setae, apical setae longest; apical segment short, apex rounded in dorsal and lateral view. Phallus tubular, basal section moderately enlarged and meeting apical section at about $120^{\circ}$; apex without process; internal processes of the phallus sclerous, in lateral view, slightly upturned externally, seta-like mesal process and lateral process sinuate, in dorsal and ventral view; dorsal periphallic membranes absent.

Female. Length of forewing 3.6-4.2 mm. Color and structure similar to male. Genitalia typical for genus.

Type material. Holotype male. BRAZIL: Espírito Santo: $15 \mathrm{~km}$ SE. of Santa Teresa, Fazenda Santa Clara, 460 m, 22.IV.1977, C.M. \& O.S. Flint Jr. leg. (MZUSP). Paratypes: same data as holotype, 7 males, 9 females (DZUP, NMNH); Rio de Janeiro: Km 54, 26 km E. of Nova Friburgo, 410 m, 19.IV.1977, C.M. \& O.S. Flint Jr. leg., 14 males, 10 females (DZUP, NMNH, MZUSP); 25.IV.1977, 1 male, 4 females (NMNH); Município Rio Claro, Rio Piraí, 09.IV.1977, C.M. \& O.S. Flint Jr. leg., 2 males (NMNH); Paraná: Jundiaí do Sul, Fazenda Monte Verde, 2326'S, 50¹6'W, 500 m, 20.X.1987, PROFAUPAR-lâmpada, 1 male; 21.X.1987, 1 male; 23.XI.1987, 1 male; 17.II.1988, 1 male (DZUP); Telêmaco Borba, Reserva Samuel Klabin, $2^{\circ} 17^{\prime}$ 'S, 50³7'W, 750 m, 04.X.1986, PROFAUPAR-lâmpada, 2 males (NMNH); 02.XI.1986, 3 males; 01.I.1987, 1 male; 27.I.1987, 1 male; 19.XI.1987, 2 males; 20.XI.1987, 3 males (DZUP); 22.XI.1987, 20 males (DZUP, NMNH); 18.I.1988, 5 males; 20.I.1988, 3 males; 21.I.1988, 3 males; 19.II.1988, 2 males; 18.IV.1988, 1 male (DZUP); Ponta Grossa, Reserva IAPAR, BR 376, 2514'S, 5003'W, 880 m, 31.X. 1986, PROFAUPAR-lâmpada, 1 male; 27.I.1987, 12 males; 28.I.1987, 3 males; 31.I.1987, 1 male (DZUP); Antonina, Reserva de Sapitanduva, $25^{\circ} 28^{\prime}$ 'S, 48 $50^{\circ} \mathrm{W}, 60$ m, 27.VIII.1987, PROFAUPAR-lâmpada, 1 male (DZUP).

Etymology. The species is named for the locality of Jundiaí where paratype specimens were collected.

\section{Smicridea (Rhyacophylax) mangaratiba sp. nov.}

Fig. 3a-d

This species would appear to be most closely related to $S$. (R.) ralphi, new species, on the basis of the shared apomorphy of the apically upturned, mesal, internal process of the phallus. They are most easily distinguished by the details of the shape of this process: in $S$. (R.) mangaratiba it is narrower and more thread-like with the apex not pointed and recurved.

Male. Length of forewing $4.1 \mathrm{~mm}$. Color overall pale yellowish brown; antennae with flagellomeres dark brown apically; head and thorax with golden setae dorsomesally and light brown setae laterally; legs pale yellowish brown with setae dark brown; forewing brown beyond anastomosis with dark marks along chord and over radial and thyridial nygmas, apex of wing with darker setae and, bordered basally by a band of pale setae. Sternum V in male with anterolateral glandular process about one and one-half times length of sternum. Genitalia as in figure 3a-d. 

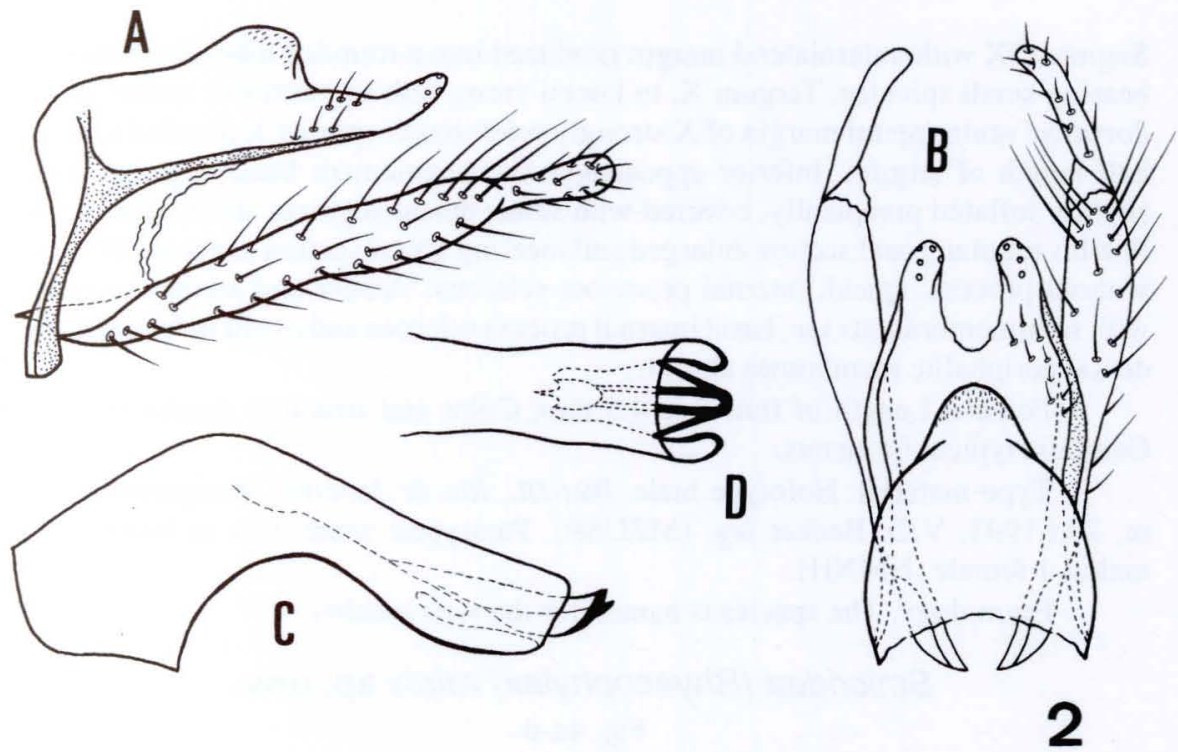

Fig. 2. Smicridea (Rhyacophylax) jundiai sp. nov., male genitalia: (A) segments IX, X, lateral, and inferior appendage; (B) same, dorsal; (C) phallus, lateral; (D) apex of same, ventral.
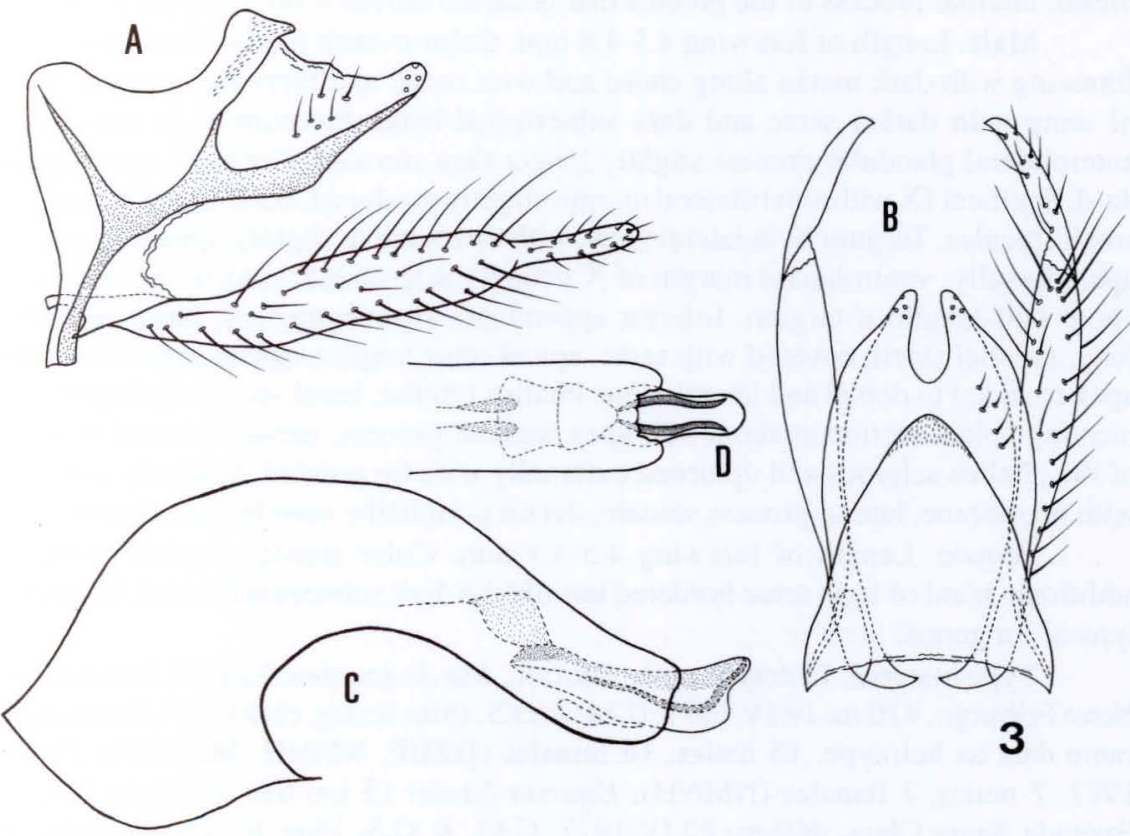

Fig. 3. Smicridea (Rhyacophylax) mangaratiba sp. nov., male genitalia: (A) segments IX, X, lateral, and inferior appendage; (B) same, dorsal; (C) phallus, lateral; (D) apex of same, ventral. 
Segment IX with anterolateral margin produced into a rounded lobe, dorsomesally bearing small spicules. Tergum $\mathrm{X}$, in lateral view, with tip rounded; setose apicodorsally; ventrolateral margin of X strongly sclerotized; apex of X divided to about half-length of tergum. Inferior appendages two-segmented; basal segment long, slightly inflated preapically, covered with setae; apical segment short, apex acute. Phallus tubular, basal section enlarged and meeting apical section at about $90^{\circ}$; apex without process; apical, internal processes sclerous, slender and sinuate, covered with semimembranous sac, basal internal process sclerous and ovoid in lateral view; dorsal periphallic membranes absent.

Female. Length of forewing $4.5 \mathrm{~mm}$. Color and structure similar to male. Genitalia typical for genus.

Type material. Holotype male. BRAzIL, Rio de Janeiro: Mangaratiba, 150 m, 20.I.1993, V.O. Becker leg. (MZUSP). Paratypes: same data as holotype, 2 males, 1 female (NMNH).

Etymology. The species is named for the type locality.

\section{Smicridea (Rhyacophylax) ralphi sp. nov.}

Fig. 4a-d

This new species and the $S$. (R.) mangaratiba, new species, appear to be closely related. Smicridea $(R$.) ralphi is most easily recognized by the shape of the mesal, internal process of the phallus that is curled dorsad with its tip pointed.

Male. Length of forewing 4.5-4.8 mm. Color overall pale yellowish brown; forewing with dark marks along chord and over radial and thyridial nygmas, apex of wing with darker setae and dark subterminal band. Sternum V in male with anterolateral glandular process slightly longer than sternum. Genitalia as in figure 4a-d. Segment IX with anterolateral margin slightly produced, dorsomesally bearing small spicules. Tergum $X$, in lateral view, with tip rounded, slightly upturned; setose apicodorsally; ventrolateral margin of X strongly sclerotized; apex of X divided to about half-length of tergum. Inferior appendages two-segmented; basal segment long, parallel sided, covered with setae, apical setae longest; apical segment short, apex rounded in dorsal and lateral view. Phallus tubular, basal section enlarged and meeting apical section at about $90^{\circ}$; apex without process; mesal, internal process of the phallus sclerous and upturned externally with tip pointed, ventrally covered with membrane, lateral process sinuate; dorsal periphallic membranes absent.

Female. Length of forewing $4.5-4.7 \mathrm{~mm}$. Color similar to male with an additional band of light setae bordered basally the dark subterminal band. Genitalia typical for genus.

Type material. Holotype male. BRAZIL, Rio de Janeiro: Km 54, $26 \mathrm{~km}$ E. of Nova Friburgo, 410 m, 19.IV.1977, C.M. \& O.S. Flint Jr. leg. (MZUSP). Paratypes: same data as holotype, 15 males, 14 females (DZUP, NMNH, MZUSP); 25.IV. 1977, 7 males, 7 females (NMNH); Espírito Santo: $15 \mathrm{~km} \mathrm{SE}$. of Santa Teresa, Fazenda Santa Clara, 460 m, 22.IV.1977, C.M. \& O.S. Flint Jr. leg., 9 males, 6 females (NMNH); São Paulo: Salesópolis (Estação Biológica Boracéia, Ribeirão Coruja), 850 m, 02.IV.1977, C.M. \& O.S. Flint Jr. leg., 1 male, 2 females (NMNH); 
Paraná: Guarapuava, Estância Água Santa Clara, 2540'S, 5201'W, 740 m, 25.II.1987, PROFAUPAR-lâmpada, 1 male; 25.IV.1987 1 male (DZUP); Ponta

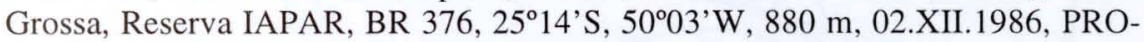
FAUPAR-lâmpada, 1 male (DZUP); 27.I.1987, 1 male (DZUP); 28.I.1987, 25 males (DZUP, NMNH); Antonina, Reserva de Sapitanduva, 2528'S, 4850'W, 60 m, 01.XII.1986, PROFAUPAR-lâmpada, 1 male;29.III.1987, 1 male; 27.VII.1987, 1 male; 19.XII. 1987, 1 male (DZUP).

Etymology. This species is named with gratitude and affection for Dr. Ralph W. Holzenthal, a Trichoptera specialist at the University of Minnesota, MN, USA.
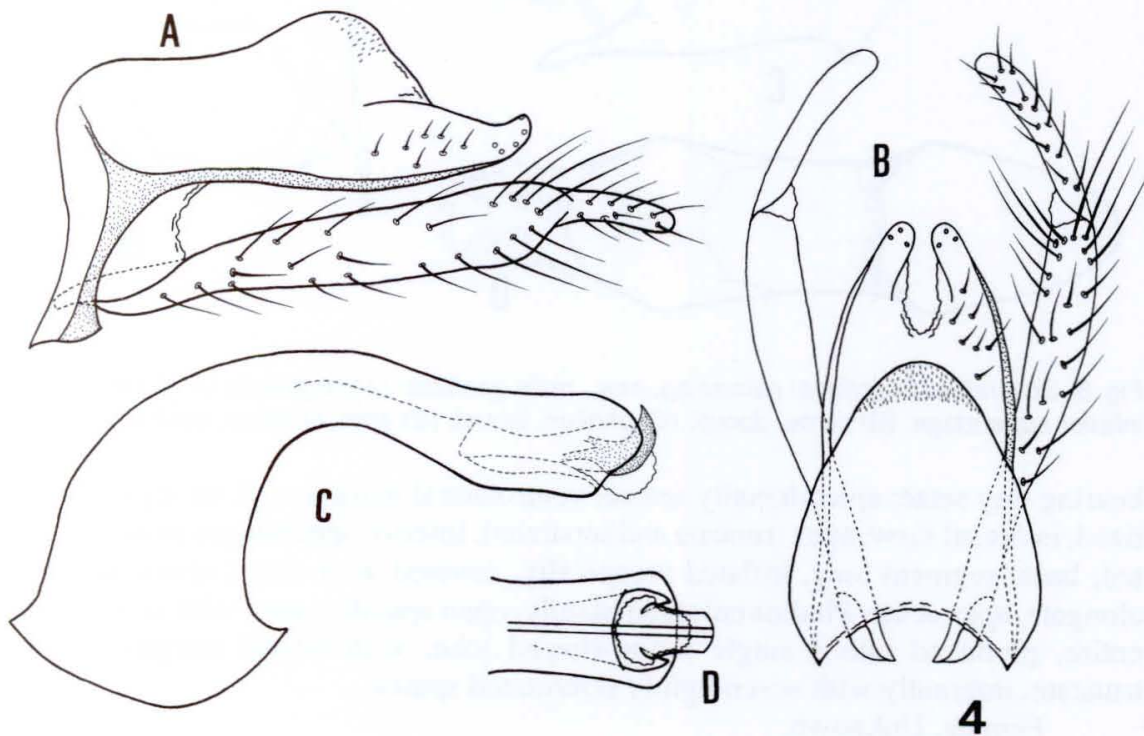

Fig. 4. Smicridea (Rhyacophylax) ralphi sp. nov., male genitalia: (A) segments IX, X, lateral, and inferior appendage; (B) same, dorsal; (C) phallus, lateral; (D) apex of same ventral.

\section{Smicridea (Smicridea) mirnae sp. nov.}

Fig. 5a-d

This new species is another member of the nigripennis group of FLINT (1974). Smicridea (S.) mirnae, new species, appears to be closest to S. (S.) latipala and $S$. (S.) pipila in the apicoventral lobe of the phallus, and also resembles $S$. (S.) pipila in the shape of tergum $\mathrm{X}$, in dorsal view. The new species is distinguished from the other species in the details of the phallic structure, especially the presence of seven small, internal spines.

Male. Length of forewing 4.0-4.5 mm. Color in alcohol, pale brown. Genitalia as in figure 5a-d. Segment IX with anterolateral margin produced into a rounded lobe, dorsomesally with small spicules. Tergum X, in lateral view, with tip upturned, 


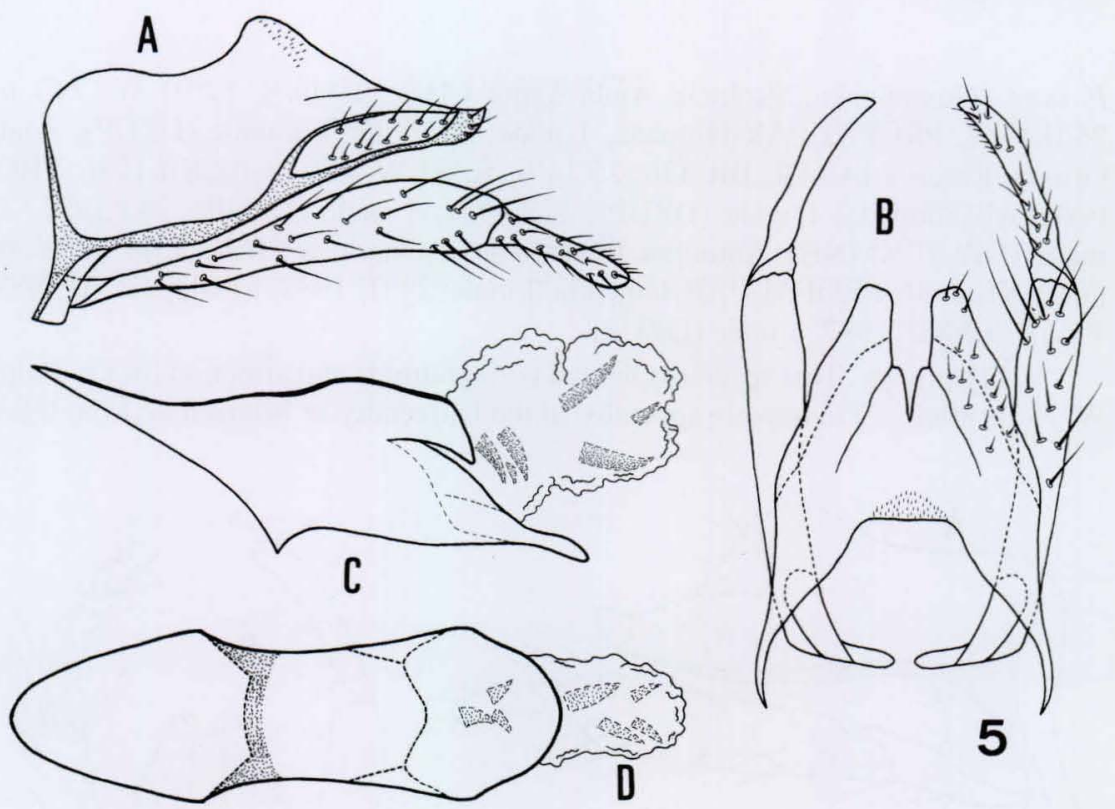

Fig. 5. Smicridea (Smicridea) mirnae sp. nov., male genitalia: (A) segments IX, X, lateral, and inferior appendage; (B) same, dorsal; (C) phallus, lateral; (D) apex of same, ventral.

bearing tiny setae; apicodorsally setose; ventrolateral margin of X strongly sclerotized; in dorsal view, apex truncate and separated. Inferior appendages two-segmented; basal segment long, inflated preapically, covered with setae; apical segment elongate, apex acute. Phallus enlarged basally, open apically; apex with ventral lobe entire, produced into a single scoop-shaped lobe, with lateral margin slightly truncate; internally with seven lightly sclerotized spines.

Female. Unknown.

Type material. Holotype male. BrazIL, Paraná: Jundiaí do Sul, Fazenda Monte Verde, 2326'S, 50¹6'W, 500 m, 25.II.1987, PROFAUPAR-lâmpada (DZUP). Paratypes: same data as holotype, 20.X.1987, 1 male; 24.X.1987, 1 male; 19.I.1988, 1 male; 17.II.1988, 1 male; 16.III.1988, 1 male (DZUP); Telêmaco Borba, Reserva Samuel Klabin, 241'ㅇ, 50³7'W, 750 m, 19.I.1988, PROFAUPAR-lâmpada, 1 male (NMNH); 16.II.1988, 1 male (DZUP).

Etymology. This species is named with gratitude and affection for Dr. Mirna Martins Casagrande, a Lepidoptera specialist of the Departamento de Zoologia, Universidade Federal do Paraná (Curitiba, Brazil), who strongly supported the very first inclination of the senior author (GLA) to the study of aquatic insects.

ACKNOWLEDGMENTS. We are grateful to Marcelo Duarte for his suggestions and comments on the manuscript. The senior author is also grateful to the Brazilian Federal Agency CAPES or its financial support during her graduate program in entomology at the Universidade Federal do Paraná and National Museum of Natural History, Smithsonian Institution (Process BEX 0386/01-4). 


\section{REFERENCES}

AlmeidA, G.L. \& L. MARINONI. 2000. Abundância e sazonalidade das espécies de Leptoceridae (Insecta, Trichoptera) capturadas com armadilha luminosa no Estado do Paraná, Brasil. Revta bras. Zool., Curitiba, 17 (2): 347-359.

BLAHNIK, R.J. 1995. New species of Smicridea (subgenus Smicridea) from Costa Rica, with revision of the fasciatella complex (Trichoptera: Hydropsychidae). Jour. North Amer. Benthol. Soc., Lawrence, 14 (1): 84-107.

FLINT JR., O.S. 1967. Studies of Neotropical caddisflies, V: types of the species described by Banks and Hagen. Proc. U.S. Nat. Mus., Washington, DC, 123 (3619): 1-37.

. 1971. Studies of Neotropical caddisflies, XII: Ryacophilidae, Glossosomatidae, Philopotamidae, and Psychomyiidae from the Amazon Basin (Trichoptera). Amazoniana, Manaus, 3 (1): 1-67.

1972. Studies of Neotropical caddis flies, XIV: on a collection from northern Argentina. Proc. Biol. Soc. Wash. 85: 223-248.

1974. Studies of Neotropical caddisflies, XVII: The genus Smicridea from North and Central America (Trichoptera: Hydropsychidae). Smithson. Contrib. Zool., Washington, DC, 167: 1-65.

1978. Studies of Neotropical caddisflies, XXII: Hydropsychidae of the Amazon Basin (Trichoptera). Amazoniana, Manaus, 6 (3): 373-421.

- 1981. Studies of Neotropical caddisflies, XXVIII: the Trichoptera of the Rio Limón Basin, Venezuela. Smithson. Contrib. Zool., Washington, DC, 330: 1-60.

- 1983. Studies of Neotropical caddisflies, XXXIII: new species from austral South America (Trichoptera). Smithson. Contrib. Zool., Washington, DC, 377: 1-100.

- 1989. Studies of Neotropical caddisflies, XXXIX: The genus Smicridea in the Chilean Subregion (Trichoptera: Hydropsychidae). Smithson. Contrib. Zool., Washington, DC, 472: 1-45.

- 1991. Studies of Neotropical caddisflies, XLV: The taxonomy, phenology, and faunistics of the Trichoptera of Antioquia, Colombia. Smithson. Contrib. Zool., Washington, DC, 520: 1-113. . 1992. Studies of Neotropical caddisflies, XLIV: on a collection from Ilha de Maracá, Brasil. Acta Amazonica, Manaus, 21: 63-83.

FLINT JR., O.S. \& D.G. Denning. 1989. Studies of Neotropical caddis flies, XL: new species of Smicridea (Smicridea) from Middle America and the West Indies (Trichoptera: Hydropsychidae) Proc. Biol. Soc. Wash. 102: 418-433.

Flint JR., O.S.; R.W. Holzenthal \& S.C. Harris. 1999. Catalog of the Neotropical caddisflies (Insecta: Trichoptera). Columbus, Special Publication, Ohio Biological Survey, IV+239p.

Holzenthal, R.W. \& R.J. Blahnik. 1995. New species of Smicridea (Rhyacophylax) (Trichoptera: Hydropsychidae) from Costa Rica. Entomol. News, Philadelphia, 106 (5): 213-223.

Marinoni, R.C. \& R.R.C. DutRA. 1993. Levantamento da fauna entomológica no Estado do Paraná, I. Introdução. Situações climáticas e florísticas de oito pontos de coleta. Dados faunísticos de agosto de 1986 a julho de 1987. Revta bras. Zool., Curitiba, 8 (1/2/3/4): 31-73.

Marinoni, L. \& G.L. DE AlmeidA. 2000. Abundância e sazonalidade das espécies de Hydropsychidae (Insecta, Trichoptera) capturadas com armadilha luminosa no Estado do Paraná, Brasil. Revta bras. Zool., Curitiba, 17 (1): 283-299.

Oliveira, L.G. \& C.G. Froehlich. 1997. The Trichoptera (Insecta) fauna of a "cerrado" stream in Southeastern Brazil. Naturalia, Rio Claro, 22: 183-197.

Received in 13.V.2002; accepted in 31.VII.2002. 